\section{Utilization of HIV/AIDS treatment services: comparing injecting drug users and other clients}

\author{
Utilização de serviços de referência para \\ - HIV/AIDS: comparando pacientes usuários \\ e não usuários de drogas injetáveis
}

\author{
Angelita Cristine de Melo ${ }^{1}$ \\ Waleska Teixeira Caiaffa 1 \\ Cibele Comini César ${ }^{2}$ \\ Ricardo Vieira Dantas 1 \\ Bernard François Couttolenc 3
}

\author{
1 Faculdade de Medicina \\ Universidade Federal \\ de Minas Gerais, \\ Belo Horizonte, Brasil. \\ 2 Instituto de Ciências \\ Exatas, Universidade \\ Federal de Minas Gerais, \\ Belo Horizonte, Brasil. \\ 3 Faculdade de Saúde \\ Pública, Universidade de \\ São Paulo, São Paulo, Brasil. \\ Correspondência \\ W. T. Caiaffa \\ Faculdade de Medicina, \\ Universidade Federal \\ de Minas Gerais. \\ Av. Alfredo Balena 190 \\ Belo Horizonte, $M G$ \\ 30130-100, Brasil. \\ wcaiaffa@medicina.ufmg.br
}

\begin{abstract}
This study compared healthcare utilization by injection drug users (IDUs) and non-IDUs. Data were abstracted from patients' medical records, admitted on HIVIAIDS treatment centers, between 1986 and 2002, forming a non-concurrent cohort study. Variables included: sociodemographics, HIVIAIDS exposure group, healthcare utilization (consultations, procedures, and prescriptions). Descriptive analyses included ageperiod and cohort effects. Out of 170 patients, with an average age of 30 years, $39.4 \%$ were IDUs, $71.8 \%$ were males and had low levels of education. At the first consultation, $86.5 \%$ neither received an ARV prescription nor had a request for CD4 or viral load. Injection drug users, as compared to non-IDUs, were less likely to receive ARV prescriptions and requests for CD4 lymphocyte and viral load counts, even though the number of consultations did not differ between the two groups. Healthcare utilization increased in calendar-year in the non-IDUs group, parallel to the implementation of the Brazilian health policy of universal care. However, this favorable trend was not observed among IDUs. Differential outcomes for HIVIAIDS among IDUs, towards worse prognosis, suggest difficulties in terms of adherence and follow-up of ARV therapy in this population.
\end{abstract}

Health Services; HIV; Acquired Immunodeficiency Syndrome; Street Drugs

\section{Introduction}

After 1996, with the advent of highly active antiretroviral therapy (HAART) and respective therapeutic protocols, a new course in the history of the HIV/AIDS epidemic has been observed 1,2,3,4,5. In Brazil, public policies targeting health services structure associated with universal access of HAART patients were decisive for the reduction of morbimortality rates and improvement of the quality of life for people living with HIV/AIDS 6 . Notwithstanding, some authors show that characteristics of the patients and providers can have negative impacts on access to and utilization of services and, consequently, on patients' management. Standing out are such factors as ethnicity, age, education, use of injection drugs, and the provider's perception (not always accurate) of the probability of a patient's adherence to therapy 4,5,6,7,8,9,10,11,12,13. Injection drug users (IDUs) are less likely to receive HAART in different contexts $4,7,8,9,10,11,12,13$, especially those who are not enrolled in syringe-exchange programs (SEP) 11,14.

According to Bassetti et al. 11, the prescriber's perception of the likelihood of a patient's adherence to treatment stands out as the mainly cause of not prescribing HAART, even when recommended. Prescribers generally evaluate adherence empirically and have low capability to further evaluate the extension of this decision 14,15 . 
There are various reports of low adherence among IDUs to antiretroviral therapy (ART) 3,11, $12,16,17,18$, with consequently less utilization of services. However, there are also indications that, after beginning treatment, IDUs show adherence similar to non-IDUs 2,11 . In any event, not prescribing HAART to patients based on their hypothetical low adherence is controversial, especially with regard to ethical issues, given the possibility of systematically denying available therapeutic resources to marginalized groups 15 .

Despite national efforts to implement public policies to control HIV infection, including universal access to HAART, there are indications that the use of injection drugs can influence (negatively) individuals' utilization of and access to these resources. To evaluate HIV/ AIDS treatment health services is justified, considering the scarcity of studies on the subject 19 and the different phases of implementation of therapeutic resources and policies 6 . In addition, comparison between IDUs and non-IDUs patients can contribute to an understanding of the role of injection drug use in the utilization of HIV/AIDS healthcare services.

\section{Methods}

This study is part of the project named Analysis of Costs and Impact of Antiretroviral Therapy 20, sponsored by the Programa Nacional de DST e AIDS (PN-DST/AIDS). It involved research in national databases and consultation of medical records of individuals living with HIV/AIDS who were attended by national reference centers for the treatment of HIV infections and AIDS. As regards this last objective, a non-concurrent cohort study was carried out.

\section{Data sample and collection}

Information on HIV/AIDS adult patient from the Hospital Dia de Itajaí, Santa Catarina, was selected, in order to compare utilization of services between IDUs and non-IDUs. The election of this specific health service was based on certain local characteristics, including the incidence of AIDS case notifications (194/100,000 inhabitants) 21,22 , the high proportion of IDUs (40.9\%), and the existence at the time of local structured health services for treating HIV/AIDS, which were comprised of a testing center, a day hospital, and an SEP. In addition, it was taken into consideration that of the total number of IDUs included in the national study $(n=77)$, the greatest percentage was observed in Itajaí $(87 \%, n=67)$.
Using random criteria, the medical records of patients in treatment for HIV/AIDS in the ambulatory and/ or day hospital segment were selected from the local list, during the period January, 1986, to June, 2002. The sample was stratified into calendar year (based on the AIDS cases reported to PN-DST/AIDS), according to the availability of antiretroviral (ARV) drugs in Brazil, as follows: 1986 to 1990, when ARV were not available; 1991 to 1995 , the beginning of ART with monotherapy and double therapy; and 1996 to 2002, when HAART was available and recommended through specifics policies aiming universal healthcare access 6 .

This subsample was obtained from a minimum sample of 368 patients for the study of medical records of national scope 23 , given the event "request for viral load" was from 90 to $95 \% 24$, using a confidence interval of $95 \%$ and a minimum antiretroviral use prevalence of $35 \%$ 20,23,24.

Patient information was registered from their admission to the service until death, transfer, abandonment, or the end of the study (June 30, 2002). Data collection was done in June, 2003, by previously trained healthcare professionals.

\section{Variables}

The structured and precoded data collection instrument included information about the individual and healthcare utilization. Individual information included sociodemographic data, sources of exposure to HIV, categorized according to the Ministry of Health criteria 25, and data on sexual partners. Healthcare utilization data included medical visit, ARV prescriptions and exam requests, including $\mathrm{T}_{\mathrm{CD} 4}$ lymphocyte counts and viral load, when possible or available.

The presence or absence of ARV prescriptions and their associations were analyzed according to their appropriateness as recognized by Brazilian guidelines 26,27,28,29. Considering that the first Brazilian guidelines went into effect in 1996, the adequacy of therapy was analyzed starting in this year 26 . To take into account the real operation of these standards, we allowed a period of six months for their implementation.

The database was structured according to all medical visits registered for each patient from 1986 to 2002 . The following variables were included: educational level, sexual partners at first visit, time period first and last visit, total number of visit, ARV prescription at first visit, number of ARV prescriptions (total and mean), adequacy of association between the different 
ART according to the current guidelines (starting in 1996), request for $\mathrm{T}_{\mathrm{CD} 4}$ and viral load counts (first request date and total number of requests).

\section{Analysis}

Analyses were subdivided into statistics and graphics. Univariate statistical analysis included comparison of distributions with the MannWhitney U test and of proportions with chisquare 30 . In order to verify probable calendar effects of the source of infection and of sex on indicators of healthcare utilization, a stratified analysis was conducted for the periods of greatest concentration of visits: 1991/1995 and 1996/ 2002. In the multivariate analysis of factors associated with requests for viral load count, logistical regression was used for each group separately (IDUs/non-IDUs). Sociodemographic variables and healthcare utilization indicators were: age at first admission to the service, sex, education, sexual partners, year of admission, number of medical visits (total and monthly), duration of care (median), indicators of ARV use, time elapsed since first visit, and viral load count. Requests for $\mathrm{T}_{\mathrm{CD} 4}$ count was not included among the model's explanatory variables because it was collinear with the determination of the event itself once the consensuses/ directives for HAART utilization recommended requesting both tests to monitor the effectiveness of treatment $26,27,28,29$ and also due to an elevated Pearson correlation $(0.871$ for nonIDUs and 0.821 for IDUs). The selection criteria for candidate variables for the multivariate model were $p$-value $\leq 0.25$, biological plausibility, epidemiological relevance, and $\mathrm{p} \leq 0.0530$.

Graphic analysis, aiming to investigate ageperiod effects 31 , included the following markers of HIV/AIDS healthcare utilization: average number of visits/month, total of $\mathrm{T}_{\mathrm{CD} 4}$ and viral load count requests. IDUs age was categorized according to age quartiles ( 18 to $27 ; 28$ to 32 ; 33 to 61 ) and calendar year according to the brackets 1990/1992, 1993/1994, 1995/2001. The software programs SPSS 11.5 (SPSS Inc., Chicago, USA) and Excel 2004 were used.

The study was carried out in accordance with Resolução n. 196/96 of the Conselho Nacional de Saúde, principally as concerns the absolute confidentiality of names of patients living with HIV/AIDS and obtaining the consent of the institutions involved. The study was approved by the Research Ethics Commissions of the Universidade de São Paulo (USP) and of the Universidade Federal de Minas Gerais (UFMG), and respective local committees.

\section{Results}

Of the 170 medical records of individuals living with HIV/AIDS that we studied, $57.1 \%$ were non-IDUs ( $\mathrm{n}=97$ ) and $39.4 \%$ were IDUs ( $\mathrm{n}=$ 67). Six registers without reference to category of exposure $(3.5 \%)$ were excluded from subsequent analyses. The average age at admission was 30.0 years $\left(\mathrm{P}_{25}: 26.0 ; \mathrm{P}_{75}: 36.0\right)$, not differing significantly $(\mathrm{p}=0.19)$ between IDUs (29.0) and non-IDUs (31.0). Regarding distribution by sex, $71.8 \%$ were males $(n=122)$ and $28.2 \%$ were females $(n=48)$, with a male:female ratio of 2.5:1.0 ( $p<0.01$; comparing IDUs, $91 \%$ and non-IDUs, $57.7 \%$ ). Almost half of the cases had less than first grade education $(48.8 \%)$, with this information being unknown for $7.6 \%$ of individuals ( $\mathrm{p}=0.59$; comparing IDUs, $50 \%$ and non-IDUs, $45.6 \%$ ). Multiple sexual partners were reported by $23.5 \%$ of patients $(n=40)$ and the absence of partners or a single partner were reported by $44.7 \%$ of patients $(n=76)$. Around $90 \%$ of IDUs reported multiple sexual partnership when compared to non-IDUs $(40.7 \%)$, a significant difference $(p<0.01)$. The number of sexual partners was unknown for $31.8 \%$ of individuals, although the absence of this information was more common among non-IDUs.

As regards healthcare utilization at the first medical visit, no ARV was prescribed for $86.5 \%$ of individuals (91\% for IDUs and $82.5 \%$ for non-IDUs, $p=0.11$ ). The number of ARV prescriptions at the first consultation did not differ significantly according to the use of injection drugs $(\mathrm{p}=0.76)$, with monotherapy in $16.7 \%$ (IDUs) and $23.5 \%$ (non-IDUs), double therapy in $66.7 \%$ (IDUs) and $41.2 \%$ (non-IDUs) and triple therapy in $16.6 \%$ (IDUs) and $35.3 \%$ (non-IDUs) (data not presented in table). The absence of requests for $\mathrm{T}_{\mathrm{CD} 4}$ counts $(61.8 \%, \mathrm{n}=$ 105) had a significantly larger percentage ( $p<$ $0.01)$ among IDUs $(77.6 \%)$ as compared to nonIDUs $(50.5 \%)$. The same pattern was encountered for requests for viral load count: absence in 132 individuals $(77.6 \%)$, of these $85.1 \%$ among IDUs and $71.7 \%$ among non-IDUs $(p=0.04)$ (Table 1). Among those that were in ART, $17 \%$ were found to be in monotherapy, $66 \%$ in double therapy, and only $17 \%$ in triple therapy.

Table 2 presents data regarding 3,217 registered medical visits, stratified for the periods $1990 / 1995$ and 1996/2002, organized to test for possible calendar effect. Between 1990/1995 no differences between IDUs and non- IDUs were encountered, neither with regard to testing nor therapeutic resources ( $p$-value varying between 0.11-0.91), possibly due to calendar effect, with access to treatment still restricted 
Sociodemographic and service utilization characteristics at first visit for individuals with HIV/AIDS, comparing IDUs and non-IDUs, 1986 to 2002.

\begin{tabular}{|c|c|c|c|c|}
\hline Characteristics & $\begin{array}{l}\text { All individuals* } \\
\quad(n=170)\end{array}$ & $\begin{array}{c}\text { IDUs } \\
(\mathrm{n}=67 ; 39.4 \%)\end{array}$ & $\begin{array}{c}\text { Non-IDUs } \\
(\mathrm{n}=97 ; 57.1 \%)\end{array}$ & 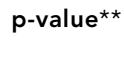 \\
\hline \multicolumn{5}{|c|}{$\begin{array}{l}\text { Sociodemographic and exposure } \\
\text { to HIV (excluded cases) }\end{array}$} \\
\hline \multirow{2}{*}{$\begin{array}{l}\text { Age at admission }(n=2) \text {, } \\
\text { mean }\left(P_{25} ; P_{75}\right)\end{array}$} & $30.0(26.0 ; 36.0)$ & $29.0(26.8 ; 33.3)$ & $31.0(25.5 ; 37.5)$ & 0.19 \\
\hline & n (\%) & n (\%) & n (\%) & \\
\hline \multicolumn{5}{|l|}{ Sex } \\
\hline Male & $122(71.8)$ & $61(91.0)$ & $56(57.7)$ & $<0.01$ \\
\hline Female & $48(28.2)$ & $6(9.0)$ & $41(42.3)$ & \\
\hline \multicolumn{5}{|l|}{ Education $(n=13)$} \\
\hline$<$ Primary incomplete & $74(43.5)$ & $31(50.0)$ & $41(45.6)$ & 0.59 \\
\hline > Primary incomplete & $83(48.5)$ & $31(50.0)$ & $49(54.4)$ & \\
\hline \multicolumn{5}{|l|}{ Sexual partners $(n=54)$} \\
\hline One/None & $76(44.7)$ & $54(90.0)$ & $22(40.7)$ & $<0.01$ \\
\hline Multiple & $40(23.5)$ & $6(10.0)$ & $32(59.3)$ & \\
\hline \multicolumn{5}{|l|}{ Healthcare utilization data } \\
\hline \multicolumn{5}{|l|}{ ARV use } \\
\hline No ARV use & $147(86.5)$ & $61(91.0)$ & $80(82.5)$ & 0.12 \\
\hline Monotherapy & $5(2.9)$ & $1(1.5)$ & $4(4.1)$ & \\
\hline Double therapy & $11(6.5)$ & $4(4.0)$ & $7(7.2)$ & \\
\hline Triple therapy & $7(4.1)$ & $1(1.5)$ & $6(6.2)$ & \\
\hline \multicolumn{5}{|l|}{ Request for $T_{C D 4}$ count } \\
\hline Requested & $65(38.2)$ & $15(22.4)$ & $48(49.5)$ & $<0.01$ \\
\hline Not requested & $105(61.8)$ & $52(77.6)$ & $49(50.5)$ & \\
\hline \multicolumn{5}{|l|}{ Request for viral load count } \\
\hline Requested & $38(22.4)$ & $10(14.9)$ & $28(28.9)$ & $<0.01$ \\
\hline Not requested & $132(77.6)$ & $57(85.1)$ & $69(71.7)$ & \\
\hline
\end{tabular}

* Statistics were done taking into account excluded cases when they existed.

** Comparing only IDUs and non-IDUs.

for both groups. Between 1996/2002, the mean total number of consultations/patient was 14.0 , ranging from 1 to 86 , without statistical distinction ( $p=0.66)$ among IDUs (7.0) and non-IDUs (14.0). The mean duration of care for all patients was 2.6 years $\left(\mathrm{P}_{25}: 1.3 ; \mathrm{P}_{75}: 5.4\right)$, also not differing according to use or nonuse of injection drugs ( $p=0.17 ; 2.0$ for IDUs and 2.2 for non-IDUs). However, the average length of time after the first visit to the first viral load count request was 52.2 months for all patients $\left(\mathrm{P}_{25}: 14.2 ; \mathrm{P}_{75}: 126.4\right)$ and differed significantly $(\mathrm{p}<0.01)$ between IDUs (56.7) and non-IDUs (19.3). The same pattern was observed for $\mathrm{T}_{\mathrm{CD} 4}$ count requests when considered unstratified: 12.4 months for the entire group $\left(\mathrm{P}_{25}: 2.1 ; \mathrm{P}_{75}\right.$ : $54.3)$, significantly different according to the use of injection drugs ( $p=0.03$ ); however, after stratification for time period, this distinction was no longer found ( $p$-value $=0.11$ for the pe$\operatorname{riod} 1990 / 1995$ and $\mathrm{p}=0.93$ for the period 1996/2002).

The mean total number of requests for viral load counts/patient was $1.0\left(\mathrm{P}_{25}: 0.0 ; \mathrm{P}_{75}: 4.0\right)$. The mean total of $\mathrm{T}_{\mathrm{CD} 4}$ counts was $3.0\left(\mathrm{P}_{25}: 1.0\right.$; $\left.\mathrm{P}_{75}: 6.0\right)$. In both cases, significant differences were observed $(p<0.01)$ between IDUs (mean viral loads $=1.0 ; \mathrm{T}_{\mathrm{CD} 4}=3.0$ ) and non-IDUs ( mean viral loads $=4.0 ; \mathrm{T}_{\mathrm{CD} 4}=5.0$ ).

A total of 1,601 ARV prescriptions were documented, with $77.3 \%$ of non-IDUs having received at least one ARV prescription as opposed to $61.2 \%$ of IDUs $(p=0.03)$. The mean number of ARV prescriptions from all consultations of each patient was $13.5\left(\mathrm{P}_{25}: 0.0 ; \mathrm{P}_{75}\right.$ : $36.0)$, with a significant difference $(\mathrm{p}<0.01)$ be- 
Univariate analysis of some indicators of service utilization of all of individuals' visits, stratified by period of admission to the service, comparing IDUs and non-IDUs.

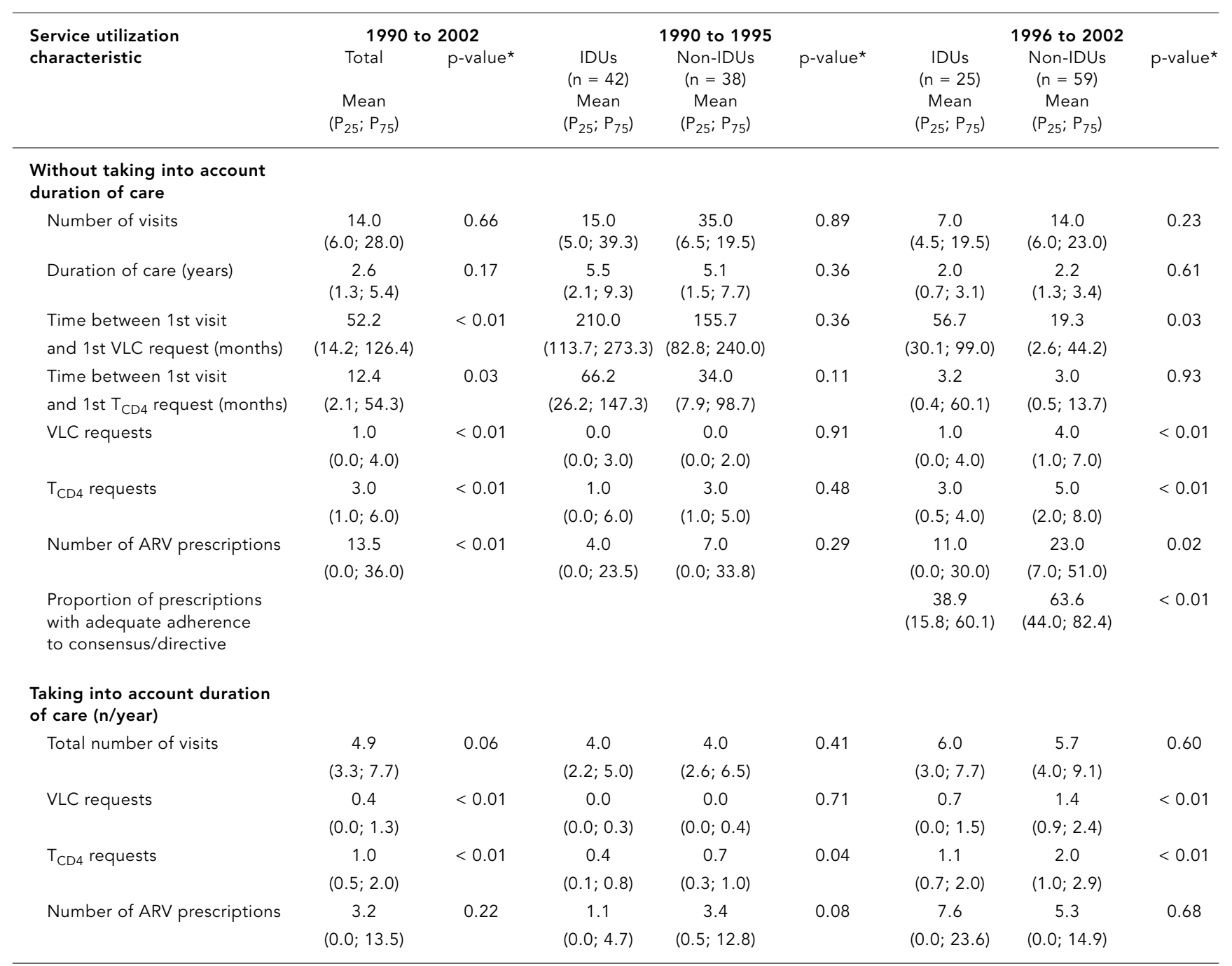

VLC = viral load count.

* P-values of all columns refer to the comparison between IDUs and non-IDUs.

tween IDUs (11.0) and non-IDUs (23.0). The proportion of ARV prescriptions that were in accordance to the current guideline were significantly $(\mathrm{p}<0.01)$ higher among non-IDUs (mean 63.6\%; $\mathrm{P}_{25}: 44.0 ; \mathrm{P}_{75}: 82.4$ ) than among IDUs (mean $38.9 \%$; $\mathrm{P}_{25}: 15.8 ; \mathrm{P}_{75}: 60.1$ ).

The variables sex and duration of care did not show evidence of significant differences during the periods analyzed for all of the healthcare utilization markers.

Verification of the effects of age, calendar, and cohort of admission to the service, comparing IDUs and non-IDUs, showed that utilization of HIV/AIDS services increased through time for IDUs and non-IDUs, equally, suggest- ing a calendar or period effect, independent of age. The mean number of visits did not show graphic differences, suggesting an cohort and/ or calendar effect between IDUs and non-IDUs (result not presented). The mean number per patient of $\mathrm{T}_{\mathrm{CD} 4}$ lymphocyte counts and viral load requests showed similar results, with distinct patterns according to the use or not of injection drugs. A positive effect of admission cohort was observed among non-IDUs for both $\mathrm{T}_{\mathrm{CD} 4}$ counts and viral load requests (Figure 1, showing only viral load), with greater values, in general, for individuals between 28 and 32 years of age, with somewhat inferior values for individuals in the age bracket 18 to 27 years, 
and even lower levels among individuals between 33 and 61 years of age. In a distinct and specific manner, this effect was not observed graphically among IDUs. Similarly, as regards calendar effect, an increase in the total number of requests was found, especially after 1995 , even though it had a distinct graphic pattern, independent of age bracket. Among IDUs, these requests varied from 0.0-4.0 per patient, although among non-IDUs there was variation of 0.0-7.0, with a sharp calendar effect, notably for the last period, where fluctuations of 4.5-7.0 requests/patient were encountered.

In the multivariate analysis, in order to investigate factors independently associated with viral load requests in any of the medical visits, with distinct models for IDUs and non-IDUs, no information was added to that obtained via univariate analysis. For non-IDUs, only the total number of ARV prescriptions remained in the final model, although for IDUs the proportion of total ARV-related prescriptions that were considered appropriate was retained.

\section{Discussion}

In this study, the majority of IDUs were enrolled in an HIV/AIDS healthcare treatment center from 1991 to 1995 , whereas non-IDUs were enrolled from 1996 to 2002. Although IDUs did not differ in terms of average number of consultations and showed longer durations of care, they had significantly less chance of receiving ARV prescriptions, and requests for $\mathrm{T}_{\mathrm{CD} 4}$ and viral load counts, whether it be at the first or subsequent visits.

From a diachronic perspective, it was observed that IDUs delayed more before obtaining test-related medical attention, that is, $\mathrm{T}_{\mathrm{CD} 4}$ and viral load counts. An increase through time was observed in healthcare utilization among non-IDUs patients, coinciding with the implementation of Brazilian public policies aimed at increasing access; however, among IDUs, such favorable impact of universal access policies were not observed.

Some authors affirm that the gains associated with the implementation of HAART are reported or less pronounced among IDUs, as compared to non-IDUs 3,12 . On the other hand, other studies found that when submitted to HAART, IDUs show similar results to other individuals living with HIV/AIDS 2,5,7,32, leaving open the debate about the influence of access to and utilization of health services and of adherence on clinical prognoses.

In this study, it was confirmed that both ARV prescriptions and requests for exams that monitor HAART differed according to the exposure category of the patients. Even considering possible effects produced by the intense activity of the epidemic and the vulnerability of the different populations it affects 33 , it was observed that IDUs as a group show less favorable indicators of service utilization, except for the total number of visits, with greater spacing between procedures. This pattern occurs despite the introduction in Brazil of public policies aimed at universal access to HIV/AIDS therapies beginning in $19966^{6}$. IDUs remain distinguished, in a distinct and negative manner, from non-IDUs, with a lower rates of ARV prescriptions and of requests for viral load and $\mathrm{T}_{\mathrm{CD} 4}$ counts, and with greater delays in requesting these exams.

Teixeira et al. 6 underlined the difficulties of access to treatment for the whole population before implementation of public policies aimed at universal access to HAART. However, as regards this population, it is also understood that other obstacles associated with the characteristics of the patients, in this case injection drug use, and of the providers appear to have negative impacts on clinical care of patients, despite an environment of universal access to HAART 4,7,8,9,10,11,12,13.

It is worth pointing out that in this study around $39 \%$ of IDUs did not receive any ARV prescription, compared to $23 \%$ of non-IDUs. Despite limitations that prevent a more detailed analysis of treatment eligibility and of the factors associated with not prescribing, other studies have estimated that from 33 to $60 \%$ of those IDUs eligible for treatment, according to the guidelines of each country and context, have never received HAART, demonstrating the universality of this problem $3,10,12,14$.

In a Swiss cohort of individuals over 16 years of age, living with HIV/AIDS, and with at least six months of care, Bassetti et al. 11 found that $25.1 \%$ of patients eligible for treatment, according to the guidelines, did not receive treatment and that IDUs were two times more likely to not receive any ARV prescription, as compared to men who have sex with men. Strathdee et al. 12 found that $60 \%$ of IDUs who were eligible for ART were not in treatment.

Some authors point out that factors associated with active drug use, with the low quality of HIV/AIDS treatment services, with medicine shortages, and with incarceration/detention of drug users could contribute to this unfavorable picture 2,8,12,14. Sociodemographic factors and IDUs behaviors also appear to be associated with not prescribing ARV: being male, being about 17 years of age at the time of first inject- 


\section{Figure 1}

Calendar year effect and cohort effect of time of admission to HIV/AIDS treatment service on total viral load requests, comparing individuals with HIV/AIDS between IDUs and non-IDUs in Itajaí, Santa Catarina, Brazil, 1990 to 2002.

1a) IDUs - calendar year effect

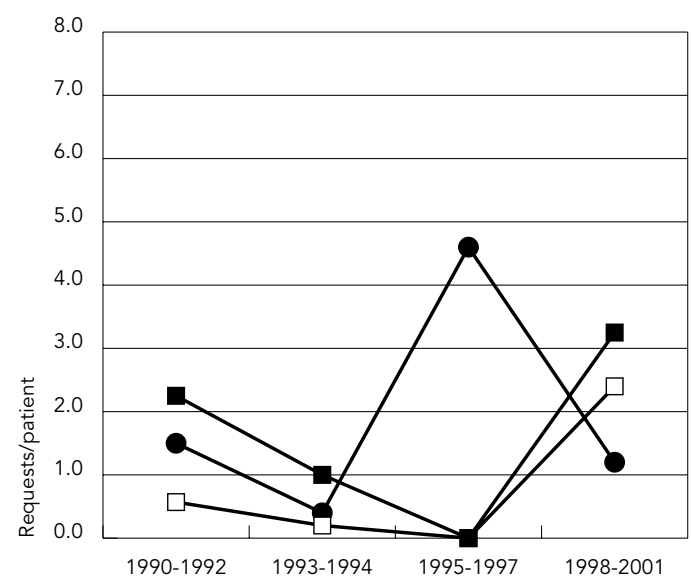

1c) IDUs - age at first admission

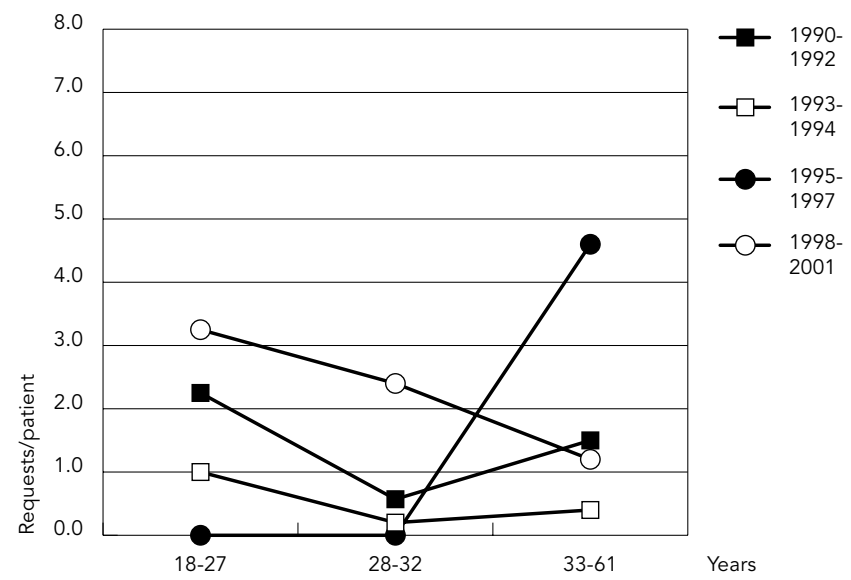

1b) Non-IDUs - calendar year effect

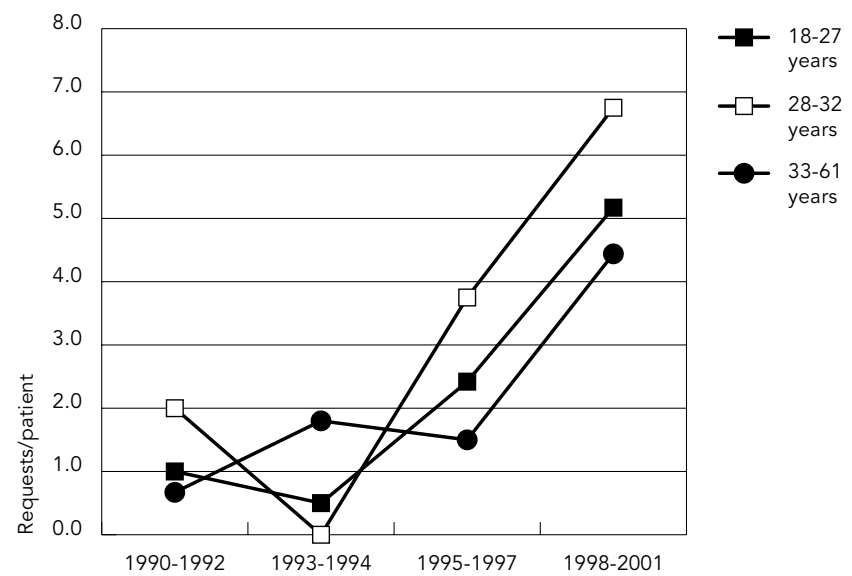

1d) Non-IDUs - age at first admission

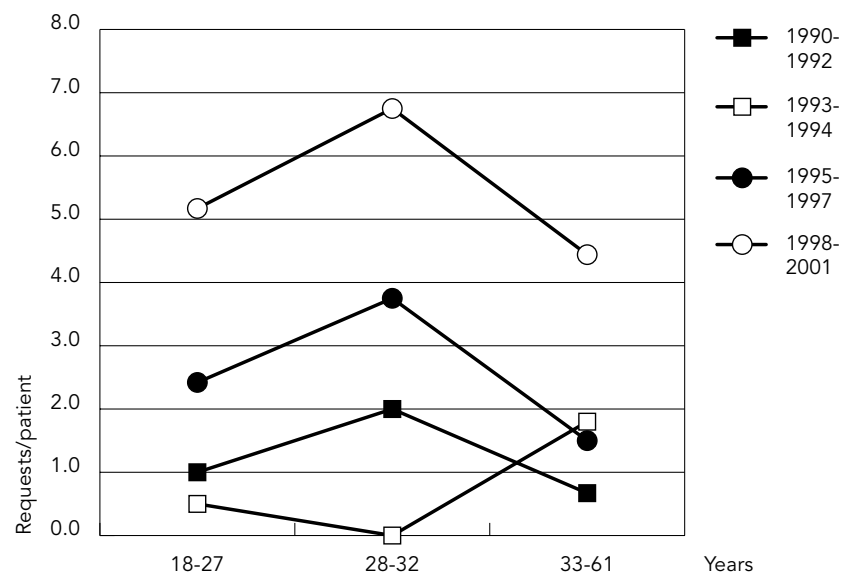

ing, not participating in harm reduction and/or alcohol treatment programs, and having a doctor who has few HIV/AIDS patients, in other words, being treated by doctors with limited HIV/AIDS experience 12.

In our study, besides the factors discussed by Strathdee et al. 12, which were partially investigated here, there could be some confusion due to the period of individuals' entry into the service coinciding with IDUs participation at the highest peak of HIV/AIDS dissemination,

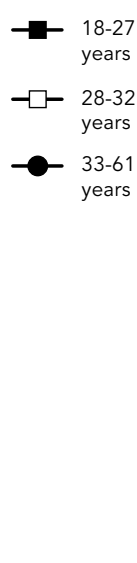

in the middle of the 1990s. At this time, HAART was also unavailable and public policies were rather contradictory regarding access to treatment. Nevertheless, this interpretation is not corroborated by the results of the stratified analysis using time period.

Also, the feminization of the epidemic after 1996, when women became a more important portion of the total population living with HIV/ AIDS, could have altered the pattern of patients under care because, as has been shown 
in diverse studies, women use health services more frequently than do men 35,36 . However, again, differences were not found as regards the specific role of women upon comparing indicators of service utilization by sex and time period.

Few studies have analyzed other indicators of HIV/AIDS service utilization, other than prescription of HAART. In a sample of HIV/AIDS patients attended in a treatment service between 1989 and 1992, Acurcio et al. 37 found an average of 17.7 consultations per year, use of zidovudine in $51.4 \%$ of patients, and more unfavorable indicators of service utilization than those found here (19.3 consultations/patient/ year and an average of 13.5 consultations during three years of observation). It is worth emphasizing that the periods analyzed by those authors was characterized by the lack of public policies regarding access to ART and of therapeutic resources for the treatment of HIV 6 , possibly giving rise to an elevated number of consultations to the detriment of effective utilization of ARV and exams for monitoring infection or illness.

Studies have focused on the difficulties involved in prescribing HAART for certain groups vulnerable to HIV/AIDS 10,11, such as IDUs. Despite the absence of studies specifically addressing requests made by medical assistants for $\mathrm{T}_{\mathrm{CD} 4}$ and viral load counts, it may be supposed that inequity in requesting these diagnostic resources, as documented in the present study, could be considered a marker of the establishment (or not) of HAART, considering that both exams are essential for monitoring the therapy $26,27,28,29$.

Shapiro et al. 10 investigated some indicators related to the possible failings of or interruptions to treatment in a Swiss cohort of patients living with HIV/AIDS. IDUs (85\%) visited services more than twice in six months (only scarcely less than the number of consultations made by men who have sex with men) and reported being attended by emergency services and hospitals more frequently (as compared to men who have sex with men). These authors argue that these indicators may be associated with a greater percentage IDUs individuals who never received ART.

Bassetti et al. 11 studied some factors associated with not prescribing HAART. According to the point of view of the providers, the primary motivation cited for not instituting this therapy when it was indicated was the supposed risk of the patient not adhering to the treatment 11 . The assumption of low adherence by IDUs occurred despite studies demonstrating that IDUs participants in harm reduction programs have similar adherence to non-IDUs 2,11 , and, on the other hand, to the recommendations for antiretroviral therapy $1,13,26,27,28,29,38$.

The low capacity of prescribers to evaluate empirically patient adherence constitutes another central parameter against using this criterion for initiating HAART. Studies emphasize the inadequacy of clinical evaluations of patient adherence, underlining the ethical questions involved in not offering treatment based on an assumption of low adherence, running the risk of marginalizing specific populations with regard to access to HAART 13,15.

Many authors propose sharing the responsibilities of adherence between the patient and the service/health professional, especially in vulnerable populations 13 . This coresponsibility for adherence would be primarily relevant in adverse social situations. Thus, health services and professionals should mediate favorable conditions for access and full utilization of available treatments, including initiatives aimed at stable living conditions, treatment for drug use and/or mental illnesses, simplification of therapeutic schemes, and also the institution of therapies with direct observation of patients 13,38

Analyzing health professionals involved in family health teams, Queiroz 39 found an elevated level of rejection of drug users and former inmates. In this study, professionals were also found to object to harm reduction proposals for such individuals $(56.8 \%$ would adopt such proposals with difficulty or would not adopt and $67.5 \%$ would not feel good about having to live with harm reduction at work), which would make the sharing of responsibilities, as proposed by Bangsberg et al. 13, exceedingly difficult.

Besides the possible influence of the social values of health professionals, this context is also characterized by structural difficulties in the health system. Cardoso et al. 40 , analyzing three SEP of a Brazilian IDUs cohort, did not find differences in the evolution towards AIDS or mortality among IDUs that frequented the SEP, as compared to those that did not frequent them. The authors, on the other hand, point out that being homeless constituted one of the most relevant predictors of unfavorable clinical evolution.

This study compares service utilization indicators between IDUs and non-IDUs, without, however, measuring the clinical outcomes or even the impact of HAART on the health and wellbeing of individuals. Also, treatment eligibility criteria and patient adherence to the ser- 
vice were not analyzed, which imposes limitations on the study.

It was also not possible to aggregate information regarding the use of SEP by IDUs undergoing HIV/AIDS treatment. Considering that the literature suggests that IDUs attended by SEP have greater rates of service utilization than others, including greater adherence to treatments $2,5,11,12,14,32$, it may be supposed that in the absence of these data, this study underestimated the differences between IDUs and non-IDUs. On the other hand, the present study's sample is comparable to those described by earlier studies done with the same population 2 , $19,33,41,42$, reaffirming its external validity.

\section{Resumo}

Objetivou-se descrever a utilização de serviços, comparando usuários de drogas injetáveis (UDIs) e nãoUDIs. Informações coletadas nos prontuários de pacientes em atendimento para HIVIAIDS, de 1986 a 2002, estabeleceram uma coorte não concorrente. As variáveis incluíam: dados sócio-demográficos, exposição ao HIVIAIDS e utilização de serviço (consultas, prescrições e solicitações de exames). Análises descritivas e verificação dos efeitos calendário e de coorte foram realizadas. Dos 170 pacientes, com trinta anos na mediana idade, 39,4\% eram UDIs, $71,8 \%$ homens e com baixa escolaridade; $86,5 \%$ não receberam, na primeira consulta, prescrição $A R V$, solicitação de $C D_{4}$ ou carga viral. Usuários de drogas injetáveis tiveram menor chance de receber prescrição de ARV, solicitação de $\mathrm{CD}_{4}$ /carga viral, seja na primeira consulta, seja nas demais, apesar de o número de consultas não diferir em virtude de ser ou não UDIs. Observou-se incremento na utilização dos serviços para pacientes não-UDIs ao longo do tempo, coincidindo com a implementação de políticas públicas visando à ampliação do acesso; porém, tal impacto não foi observado entre UDIs. Evolução diferencial da infecção pelo HIV, com piores prognósticos entre os UDIs, sugere deficiências na adesão e manutenção do tratamento ARV.

Serviços de Saúde; HIV; Síndrome de Imunodeficiência Adquirida; Drogas Ilícitas
Another limitation that should be discussed is the source of information, patients' medical records. The possibility of bias caused by differential recording of IDUs information cannot be discarded. Again, the impossibility of any estimate of access to health services and effective use of ART should be emphasized, limiting the present study to the intent of treatment.

As we did not analyze the medical and clinical justifications for not starting HAART, nor individuals' eligibility for therapies, future studies will be necessary to better elucidate the relationships between patterns of diagnosis, prescription, and injection drug use, as well as aspects related to the adherence of these populations to health services.

\section{Contributors}

B. F. Couttolenc contributed to designing the study and organizing data collection and structure. W. T. Caiaffa coordinated field collection and participated in structuring the databases and analyses. A. C. Melo participated in designing the study, field collection, structuring the databases, analyses and discussion. R. V. Dantas collaborated in structuring the databases. C. C. César participated in information analyses.

\section{Acknowledgements}

This study was done by the Universidade de São Paulo and the Universidade Federal de Minas Gerais, with the technical and financial assistance of Programa Nacional de DST e AIDS.

Dr. W. T. Caiaffa is a recipient of the Conselho Nacional de Desenvolvimento Científico e Tecnológico (CNPq) scholarship. 


\section{References}

1. Carpenter CC, Fischl MA, Hammer SM, Hirsch MS, Jacobsen DM, Katzenstein DA, et al. Antiretroviral therapy for HIV infection in 1997. Updated recommendations of the International AIDS Society-USA panel. JAMA 1997; 277:1962-9.

2. Mocroft A, Madge S, Johnson AM, Lazzarin A Clumeck N, Goebel FD, et al. A comparison of exposure groups in the EuroSIDA study: starting highly active antiretroviral therapy (HAART), response to HAART, and survival. J Acquir Immune Defic Syndr 1999; 22:369-78.

3. Poundstone KE, Chaisson RE, Moore RD. Differences in HIV disease progression by injection drug use and by sex in the era of highly active antiretroviral therapy. AIDS 2001; 15:1115-23.

4. Kahn JG, Zhang X, Cross JG, Palacio H, Birkhead GS, Morin SF. Access to and use of HIV antiretroviral therapy: variation by race/ethnicity in two public insurance programs in the U.S. Public Health Rep 2002; 117:252-62.

5. Mocroft A, Gatell J, Reiss P, Ledergerber B, Kirk O, Vella S, et al. Causes of death in HIV infection: the key determinant to define the clinical response to anti-HIV therapy. AIDS 2004; 18:2333-7.

6. Teixeira PR, Vitoria MA, Barcarolo J. Antiretroviral treatment in resource-poor settings: the Brazilian experience. AIDS 2004; 18 Suppl 3:S5-7.

7. Chaisson RE, Keruly JC, Moore RD. Race, sex, drug use, and progression of human immunodeficiency virus disease. N Engl J Med 1995; 333:751-6.

8. Schoenbaum EE, Lo Y, Floris-Moore M. Predictors of hospitalization for HIV-positive women and men drug users, 1996-2000. Public Health Rep 2002; 117:60-7.

9. Waidmann TA, Rajan S. Race and ethnic disparities in health care access and utilization: an examination of state variation. Med Care Res Rev 2000; 57 Suppl 1:55-84.

10. Shapiro MF, Morton SC, McCaffrey DF, Senterfitt JW, Fleishman JA, Perlman J, et al. Variations in the care of HIV-infected adults in the United States: Results From the HIV Cost and Services Utilization Study. JAMA 1999; 281:2305-15.

11. Bassetti S, Battegay M, Furrer H, Rickenbach M, Flepp M, Kaiser L, et al. Why is highly active antiretroviral therapy (HAART) not prescribed or discontinued? Swiss HIV Cohort Study. J Acquir Immune Defic Syndr 1999; 21:114-9.

12. Strathdee SA, Palepu A, Cornelisse PG, Yip B, O'Shaughnessy MV, Montaner JS, et al. Barriers to use of free antiretroviral therapy in injection drug users. JAMA 1998; 12:547-9.

13. Bangsberg D, Tulsky JP, Hecht FM, Moss AR. Protease inhibitors in the homeless. JAMA 1997; 278:63-5.

14. Vlahov D, Celentano DD. Access to highly active antiretroviral therapy for injection drug users: adherence, resistance, and death. Cad Saúde Pública 2006; 22:705-31.

15. Sollitto S, Mehlmana M, Youngner S, Lederman MM. Should physicians withhold highly active antiretroviral therapies from HIV-AIDS patients who are thought to be poorly adherent to treatment? AIDS 2001; 15:153-9.
16. Nemes MIB, Carvalho HB, Souza MFM. Antiretroviral therapy adherence in Brazil. AIDS 2004; 18 Suppl 3:S15-20.

17. Carvalho CV, Duarte DB, Merchán-Hamann E, Bicudo E, Laguardia J. Determinantes da aderência à terapia anti-retroviral combinada em Brasília, Distrito Federal, Brasil, 1999-2000. Cad Saúde Pública 2003; 19:593-604.

18. Freeman RC, Rodriguez GM, French JF. Compliance with AZT treatment regimen of HIV-seropositive injection drug users: a neglected issue. AIDS Educ Prev 1995; 8:58-71.

19. Pechansky F, Inciardi JA, Surratt H, Lima AFBS Kessler FP, Soibelman M, et al. Estudo sobre as características de usuários de drogas injetáveis que buscam atendimento em Porto Alegre, RS. Rev Bras Psiquiatr 2000; 22:164-71.

20. Couttolenc BF, Caiaffa WT, Pluciennick AMA, Santos, NJ, Waldvogel B, Marques HHS, et al. Análise de custo e impacto da terapia anti-retroviral. São Paulo: Faculdade de Saúde Pública, Universidade de São Paulo/Coordenação Nacional DST/AIDS, Organização das Nações Unidas para a Educação, a Ciência e a Cultura; 2004.

21. Ministério da Saúde. Informações de saúde: população residente - Brasil. http://tabnet.datasus. gov.br/cgi/tabcgi.exe?ibge/cnv/popbr.def (accessed on 25/Jun/2005).

22. Ministério da Saúde. Dados e pesquisas em DST e AIDS: dados de AIDS. http://www.AIDS.gov.br/ tabnet_AIDS.htm (accessed on 25/Jun/2005).

23. Ministério da Saúde. Informações de saúde: população residente - Brasil. http:/ / www.AIDS.gov. br/tabnet_AIDS.htm (accessed on 13/Mar/2005).

24. Lwanga SK, Lemeshow S. Sample size determination in health studies: a practical manual. Geneva: World Health Organization; 1991.

25. Ministério da Saúde. Modificação da hierarquização das categorias de exposição dos casos de aids. Boletim Epidemiológico AIDS 2002; 1:45.

26. Ministério da Saúde. Consenso sobre terapia anti-retroviral em adultos: 1996. http://www.AIDS gov.br (accessed on 10/Nov/2004).

27. Ministério da Saúde. Consenso sobre terapia anti-retroviral em adultos e adolescentes infectados pelo HIV: 1997. http:/ / www.AIDS.gov.br (accessed on 10/Nov/2004).

28. Ministério da Saúde. Consenso sobre terapia anti-retroviral em adultos e adolescentes infectados pelo HIV: 1998. http://www.AIDS.gov.br (accessed on $10 /$ Nov/2004).

29. Ministério da Saúde. Consenso sobre terapia anti-retroviral em adultos e adolescentes infectados pelo HIV: 2000. http://www.AIDS.gov.br (accessed on 10/Nov/2004).

30. Fisher LD, Belle GV. Biostatistics: a metodology for health sciences. New York: John Wiley \& Sons; 1993.

31. Kleinbaum DG, Kupper LL, Morgenstern H. Epidemiologic research: principles and quantitative methods. New York: Lifetime Learning Publications, Van Nostrand Reinhold Publishing Co.; 1982.

32. Junghans C, Low N, Chan P, Witschi A, Vernazza P, Egger M. Uniform risk of clinical progression despite differences in utilization of highly active an- 
tiretroviral therapy: Swiss HIV Cohort Study. AIDS 1999; 13:2547-54.

33. Caiaffa WT, Mingoti SA, Proietti FA, CarneiroProietti AB, Silva RC, Lopes AC, et al. Estimation of the number of injecting drug users attending an outreach syringe-exchange program and infection with human immunodeficiency virus (HIV) and hepatitis $\mathrm{C}$ virus: the AjUDE-Brasil project. J Urban Health 2003; 80:106-14.

34. Boily MC, Bastos FI, Desai K, Masse B. Changes in the transmission dynamics of the HIV epidemic after the wide-scale use of antiretroviral therapy could explain increases in sexually transmitted infections: results from mathematical models. Sex Transm Dis 2004; 31:100-13.

35. Barnes PM, Adams PF, Schiller JS. Summary health statistics for the U.S. population: National Health Interview Survey, 2001. Vital Health Stat 10 2003; (217):1-82.

36. Pleis JR, Schiller JS, Benson V. Summary health statistics for U.S. adults: National Health Interview Survey, 2000. Vital Health Stat 10 2003; (215):1-132.

37. Acurcio FA, Cesar CC, Guimarães, MDC. Health care utilization and survival among patients with AIDS in Belo Horizonte, Minas Gerais, Brazil. Cad Saúde Pública 1998; 14:811-20.
38. Organización Mundial de la Salud. Expansión del Tratamiento Antirretroviral en los Entornos con Recursos Limitados: directrices para un enfoque de salud pública - Resumen de orientación. Geneva: Organización Mundial de la Salud; 2004.

39. Queiroz IS. Adoção de ações de redução de danos direcionadas aos usuários de drogas: concepções e valores de equipes de Programa de Saúde da Família [Dissertação de Mestrado]. Belo Horizonte: Faculdade de Filosofia e Ciências Humanas, Universidade Federal de Minas Gerais; 2005.

40. Cardoso MN, Caiaffa WT, Mingoti SA; Projeto AjUDE-Brasil II. AIDS incidence and mortality in injecting drug users: the AjUDE-Brasil II Project. Cad Saúde Pública 2006; 22:827-37.

41. Ferreira AD, Caiaffa WT, Bastos FI, Mingoti SA; Projeto AjUDE-Brasil II. Injecting drug users who are (un)aware of their HIV serostatus: findings from the multi-center study AjUDE-Brasil II. Cad Saúde Pública 2006; 22:815-26.

42. Aceijas C, Stimson GV, Hickman M, Rhodes T. Global overview of injecting drug use and HIV infection among injecting drug users. AIDS 2004; 18: 2295-303.

Submitted on 06/Apr/2005

Final version resubmitted on 10/Nov/2005 Approved on 16/Nov/2005 